\title{
STEROID PRODUCTION BY THE ISOLATED RABBIT OVARIAN FOLLICLE
}

\section{EFFEGTS OF OVINE LH}

\author{
E. V. YOUNGLAI \\ Department of Obstetrics and Gynecology, McMaster University, \\ Health Sciences Centre, Hamilton, Ontario, Canada L8S 479
}

(Received 26th November 1973)

\begin{abstract}
Summary. Graafian follicles from mature New Zealand white rabbits were incubated for $4 \mathrm{hr}$ at $37^{\circ} \mathrm{C}$ with air as the gas phase. The medium was changed every $15 \mathrm{~min}$ for $1 \mathrm{hr}$. Medium containing ovine LH was then added for four consecutive medium changes. Samples of the medium were analysed for $17 \beta$-hydroxyandrogens, oestrogens and progestins by radioimmunoassay procedures. When no LH was present, progestin and $17 \beta$-hydroxyandrogen secretion declined to negligible levels within $2 \mathrm{hr}$. Addition of $10 \mu \mathrm{g}$ ovine $\mathrm{LH}$ to the medium for $1 \mathrm{hr}$ caused an increase in $17 \beta$-hydroxyandrogen secretion which continued for the duration of the experiment. No significant change was observed in oestrogen secretion but there was a slight increase in progestin secretion. Addition of $5 \mu \mathrm{g}$ and $1 \mu \mathrm{g} \mathrm{LH}$ for $15 \mathrm{~min}$ also caused an elevation of $17 \beta$ hydroxyandrogen secretion within $1 \mathrm{hr}$ whereas progestin secretion took longer to increase and no change in oestrogen secretion was observed. No effect was observed with LH concentrations of less than $500 \mathrm{pg} / \mathrm{ml}$ for $1 \mathrm{hr}$, but 1 and $10 \mathrm{ng} \mathrm{LH} / \mathrm{ml}$ also caused an increase in $17 \beta$-hydroxyandrogen secretion. Oestrogen secretion was also stimulated at these levels. Control incubations with interstitial tissue showed no oestrogen secretion, slight secretion of $17 \beta$-hydroxyandrogens and greater secretion of progestin which was stimulated by exogenous LH.
\end{abstract}

\section{INTRODUCTION}

Evidence that the mammalian ovary secretes androgens was first provided by Hill (1937) who showed that ovarian grafts can restore seminal vesicle and prostate glands of castrated male mice. In the human polycystic ovary syndrome when androgens are secreted in large amounts (Abraham, Marshall \& Daane, 1972), it is believed that the ovarian stroma provides the source of these androgens (Savard, Marsh \& Rice, 1965). The interstitial tissue of rabbit ovaries has an endocrine rôle in facilitating gonadotrophin release through 20 $\alpha$-hydroxypregn-4-en-3-one (Hilliard, Spies \& Sawyer, 1969). Rabbit ovaries can produce androgens in vivo (Hilliard, Scaramuzzi \& Pang, 1973; YoungLai, 1973a) as well as in vitro (Gospodarowicz, 1964; Mills \& Savard, 1972, 1973; Coulson, Liu, Morris \& Gorski, 1972). In the latter studies, radioactive precursors were used to examine steroidogenesis. 
The present investigation was undertaken to determine testosterone (17 $\beta$ hydroxyandrogen) production by the isolated rabbit follicle and the effects of exogenous $\mathrm{LH}$ on this production. Oestrogen and progestin secretion were also examined at the same time to ascertain whether changes in androgen secretion are accompanied by changes in oestrogen and progestin secretion.

\section{MATERIALS AND METHODS}

Unless otherwise stated, the materials and methods were the same as those previously described (YoungLai, 1972a). Mature New Zealand white rabbits were anaesthetized and their ovaries were removed. Usually, two to three animals were used to provide follicles which were then randomly allotted to groups of five to twelve. The follicles were slit and incubated in 1-ml portions of medium consisting of Hanks balanced salt solution (BSS): Medium 199: normal rabbit serum (55:30:15, by vol.). The follicles were placed in the centre wells of $60 \times 15 \mathrm{~mm}$ organ tissue culture dishes (Falcon Plastics) with the outer absorbent ring soaked in BSS. The medium was replaced every 15 min and the withdrawn samples were stored at $-15^{\circ} \mathrm{C}$ until assayed. Incubations were performed at $37^{\circ} \mathrm{C}$ in a National $\mathrm{CO}_{2}$ incubator, with air as the gas phase. In some experiments, interstitial tissue was substituted for follicles. Ovine LH (NIH-LH-S-16) was added to the incubation media during the following procedures: (i) $10 \mu \mathrm{g} \mathrm{LH} / \mathrm{ml}$ at medium changes 5 to 8 , i.e. $1-\mathrm{hr}$ exposure to LH-four experiments with follicles; (ii) $500 \mathrm{ng} \mathrm{LH} / \mathrm{ml}$ as in (i) - two experiments; (iii) $10 \mathrm{ng} \mathrm{LH} / \mathrm{ml}$ as in (i) —one experiment; (iv) $1 \mathrm{ng} \mathrm{LH} / \mathrm{ml}$ as in (i) one experiment; (v) $250 \mathrm{pg} \mathrm{LH} / \mathrm{ml}$ as (i) one experiment; (vi) $500 \mathrm{pg} \mathrm{LH} / \mathrm{ml}$ as in (i) but follicles were kept at $4^{\circ} \mathrm{C}$ overnight and then stimulated for $1 \mathrm{hr}$ with $5 \mu \mathrm{g} \mathrm{LH}$-one experiment; (vii) $5 \mu \mathrm{g} \mathrm{LH} / \mathrm{ml}$ at medium change 5 , i.e. 15-min exposure of follicles to $\mathrm{LH} \longrightarrow$ one experiment; (viii) $1 \mu \mathrm{g} \mathrm{LH} / \mathrm{ml}$ as in (vii) -one experiment; (ix) same conditions as in (i)-two experiments with interstitial tissue.

Duplicate control experiments without any added $\mathrm{LH}$ were performed with follicles as well as interstitial tissue. Supplies of $\left[6,7-{ }^{3} \mathrm{H}\right]$ oestradiol- $17 \beta$ (48 $\mathrm{Ci} / \mathrm{mmol}),\left[1,2-{ }^{3} \mathrm{H}\right]$ testosterone, $(45 \mathrm{Ci} / \mathrm{mmol})$ and $\left[1,2-{ }^{3} \mathrm{H}\right]$ progesterone $(50.3 \mathrm{Ci} / \mathrm{mmol}$ were purchased from the New England Nuclear Corporation and were checked for purity by paper chromatography before use. Radioactivity was measured in a Beckman LS200 liquid scintillation spectrometer.

Radioimmunoassays were carried out as outlined previously (YoungLai, 1972a, 1973a). No chromatography step was included in the assays. Thus, for the oestrogen assay, the method probably measured only oestrone and oestradiol which are the oestrogens made and secreted by the rabbit follicle (Mills, Davies \& Savard, 1971). Since the testosterone antiserum cross-reacts with $17 \beta$-hydroxy- $5 \alpha$-androstan-3-one (dihydrotestosterone), the results have been expressed as $17 \beta$-hydroxyandrogens although we have not been able to isolate dihydrotestosterone in incubations of follicles with labelled testosterone and androstenedione (YoungLai, 1972a). The progesterone antiserum cross-reacts with 17 $\alpha$-hydroxyprogesterone and other adrenal corticoids but not to any great extent with 20 $\alpha$-hydroxypregn-4-en-3-one (Abraham, Swerdloff, Tul- 
chinsky \& Odell, 1971). Media were diluted 1:5 in Buffer A and different aliquots were taken for direct assay. The results represent total progestins, the bulk of which consists of progesterone and 17 $\alpha$-hydroxyprogesterone. In all assays, immunoreactivity of medium alone was substracted from the results. These values were very low even when medium alone was incubated for up to $8 \mathrm{hr}$.

Statistical analysis was carried out as outlined by Snedecor \& Cochran (1967).

\section{RESULTS}

The secretion patterns of the three groups of steroids by isolated follicles without exogenous LH are shown in Text-fig. 1. The follicles, obtained from three rabbits with uteri weighing $9 \cdot 80,22.46$ and $15.49 \mathrm{~g}$, were incubated six to a dish

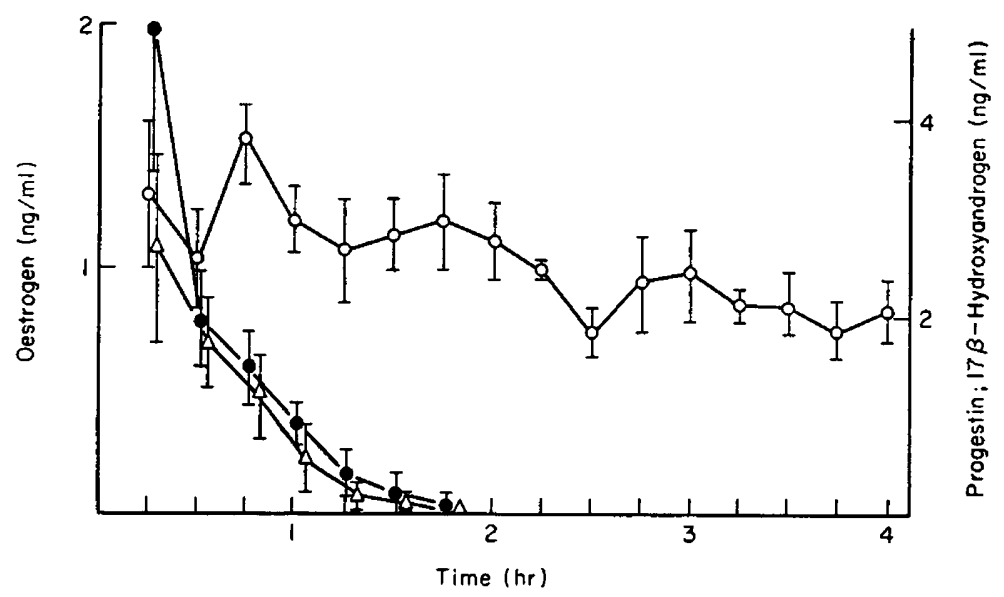

TEXT-FIG. 1. Steroid secretion by rabbit follicles. The results are expressed as the mean and standard error of two experiments. $0,17 \beta$-Hydroxyandrogen; 0 , oestrogen; $\Delta$, progestin.

without LH. It is evident from Text-fig. 1 that secretion of progestins and $17 \beta$ hydroxyandrogens was negligible within $2 \mathrm{hr}$. Oestrogen values, however, showed a steady release which tended to decline at the end of the $4 \mathrm{hr}$.

When medium containing $10 \mu \mathrm{g} \mathrm{LH} / \mathrm{ml}$ was added during the $2 \mathrm{nd} \mathrm{hr}$ of incubation, there was a dramatic increase in secretion of $17 \beta$-hydroxyandrogen whereas there was no significant change in oestrogen and only a slight increase in progestin (Text-fig. 2). In two of the four experiments, eight follicles each were used (two rabbits with uterine weights of 7.89 and $7.36 \mathrm{~g}$ ); in the other two experiments, the follicles from two rabbits (uterine weights of 21.85 and $13.61 \mathrm{~g}$ ) were divided into three groups of five. The follicles in two of these latter groups were incubated with $\mathrm{LH}$ while those in the third were homogenized in $1 \mathrm{ml}$ medium and analysed for steroids. Values for the homogenate were $3.9 \mathrm{ng}$ $17 \beta$-hydroxyandrogens $/ \mathrm{ml}, 1.3 \mathrm{ng}$ oestrogens $/ \mathrm{ml}$ and $24 \mathrm{ng}$ progestin $/ \mathrm{ml}$. The 


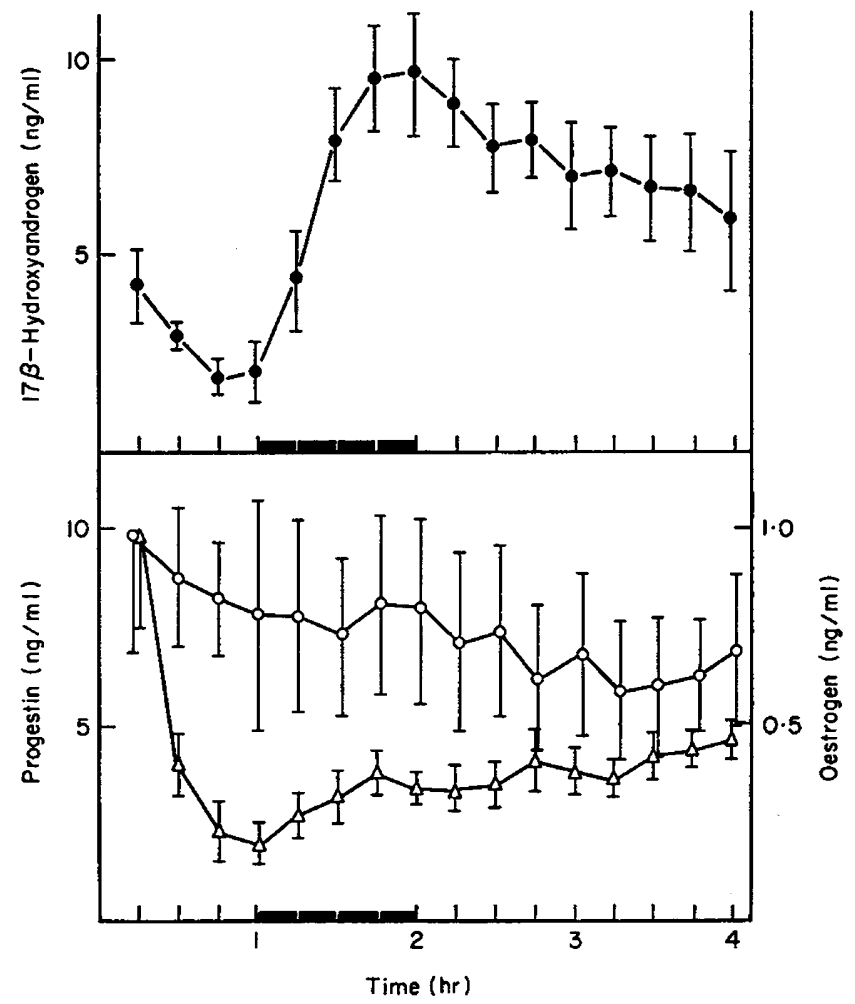

TEXT-FIG. 2. Effect on steroid secretion by rabbit follicles of exposure to $10 \mu \mathrm{g} \mathrm{LH} / \mathrm{ml}$ for $1 \mathrm{hr}$. The results represent the mean and standard error of four experiments. $\mathbf{Q}$, $17 \beta$-Hydroxyandrogen; $O$, oestrogen; $\Delta$, progestin. The bars represent the LH administration.

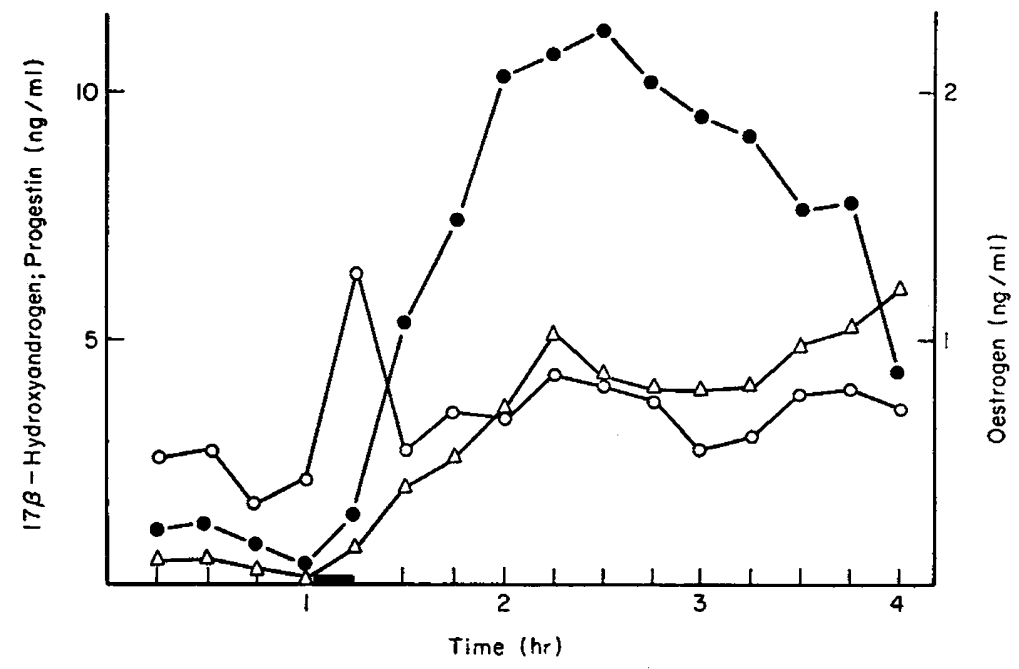

TExT-FIG. 3. Effect on steroid secretion by rabbit follicles of exposure to $5 \mu \mathrm{g} \mathrm{LH} / \mathrm{ml}$ for 15 $\min$. $17 \beta$-Hydroxyandrogen; $O$, oestrogen; $\Delta$; progestin. The bar represents the $L H$ administration. 
corresponding values for the homogenates at the end of all four experiments were $4.04 \pm 3.3 \mathrm{ng} / \mathrm{ml}, 1.04 \pm 0.76 \mathrm{ng} / \mathrm{ml}$ and $15.9 \pm 5 \cdot 1 \mathrm{ng} / \mathrm{ml}$, respectively.

When the dose of $\mathrm{LH}$ was reduced to $5 \mu \mathrm{g} / \mathrm{ml}$ and the duration of exposure decreased to $15 \mathrm{~min}$, there was a marked increase in $17 \beta$-hydroxyandrogen secretion. Twelve follicles were used from two rabbits (uterine weights of 2.42 and $6.13 \mathrm{~g})$. Text-figure 3 shows the pattern of steroid secretion from these follicles. Doses of $1 \mu \mathrm{g}, 500 \mathrm{ng}, 10 \mathrm{ng}$, and $1 \mathrm{ng}$ (Procedures ii to iv inclusive, and viii) gave essentially the same responses as those shown in Textfig. 3, except that there was a two- to threefold increase in oestrogen secretion.

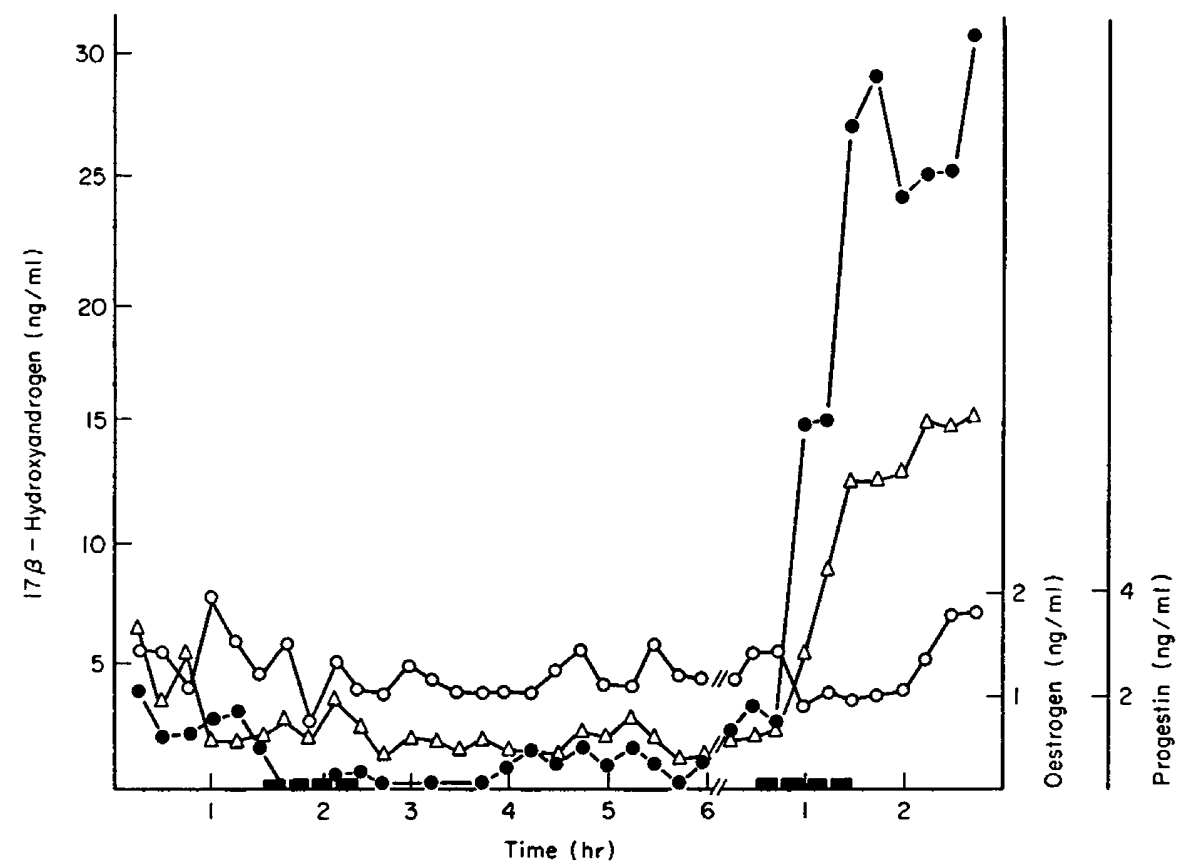

TEXT-FIG. 4. Effect on steroid secretion by rabbit follicles of exposure to $500 \mathrm{pg} \mathrm{LH} / \mathrm{ml}$ for $1 \mathrm{hr}$ and $5 \mu \mathrm{g} \mathrm{LH} / \mathrm{ml}$ for $1 \mathrm{hr}$ after storage at $4^{\circ} \mathrm{C}$ for $15 \mathrm{hr}$. Samples from $1 \frac{1}{2}$ to $2 \frac{1}{2} \mathrm{hr}$ were collected after treatment with $500 \mathrm{pg} \mathrm{LH} / \mathrm{ml}$. The discontinuity of the graphs represents overnight storage at $4^{\circ} \mathrm{C}$. Then, at $\frac{1}{2}$ to $1 \frac{1}{2} \mathrm{hr}, 5 \mu \mathrm{g} \mathrm{LH} / \mathrm{ml}$ was added at each medium change. $0,17 \beta$-Hydroxyandrogen; $O$, oestrogen; $\Delta$, progestin. The bars indicate the time of exposure to LH.

Exposure of follicles to $\mathrm{LH}$ at levels of less than $500 \mathrm{pg}$ (Procedures v and vi) for $1 \mathrm{hr}$ failed to elicit any response. All steroid levels declined as shown by the data in Text-fig. 1 . When the same follicles were incubated the next day, having been kept at $4^{\circ} \mathrm{C}$ overnight, a good response to $5 \mu \mathrm{g} \mathrm{LH} / \mathrm{ml}$ for $1 \mathrm{hr}$ was observed (Text-fig. 4). A total of nineteen follicles obtained from two rabbits with uteri weighing 6.54 and $6.71 \mathrm{~g}$ were used. Progestin and $17 \beta$-hydroxyandrogen secretion increased after LH stimulation but the response of the latter was much greater than that of the former.

When interstitial tissue from mature rabbits (the same as those used for the data of Text-fig. 3) was checked for the secretion of steroids, oestrogens and 
$17 \beta$-hydroxyandrogens were only detected in minute amounts in the first three samples. Progestin values were initially high and then decreased to low levels and remained low but detectable for the duration of the incubations. The homogenates at the end of the incubations had the equivalent of 7.2 and $5.6 \mathrm{ng} / \mathrm{ml}$ progestin. Oestrogens and $17 \beta$-hydroxyandrogens were not detectable. On addition of LH to interstitial tissue (two rabbits, uterine weights of 5.65 and $7.44 \mathrm{~g}$ ), there was a gradual increase in progestin secretion within $1 \mathrm{hr}$ followed by a larger increase in the 4th hour (Text-fig. 5). Tissue homogenates at the

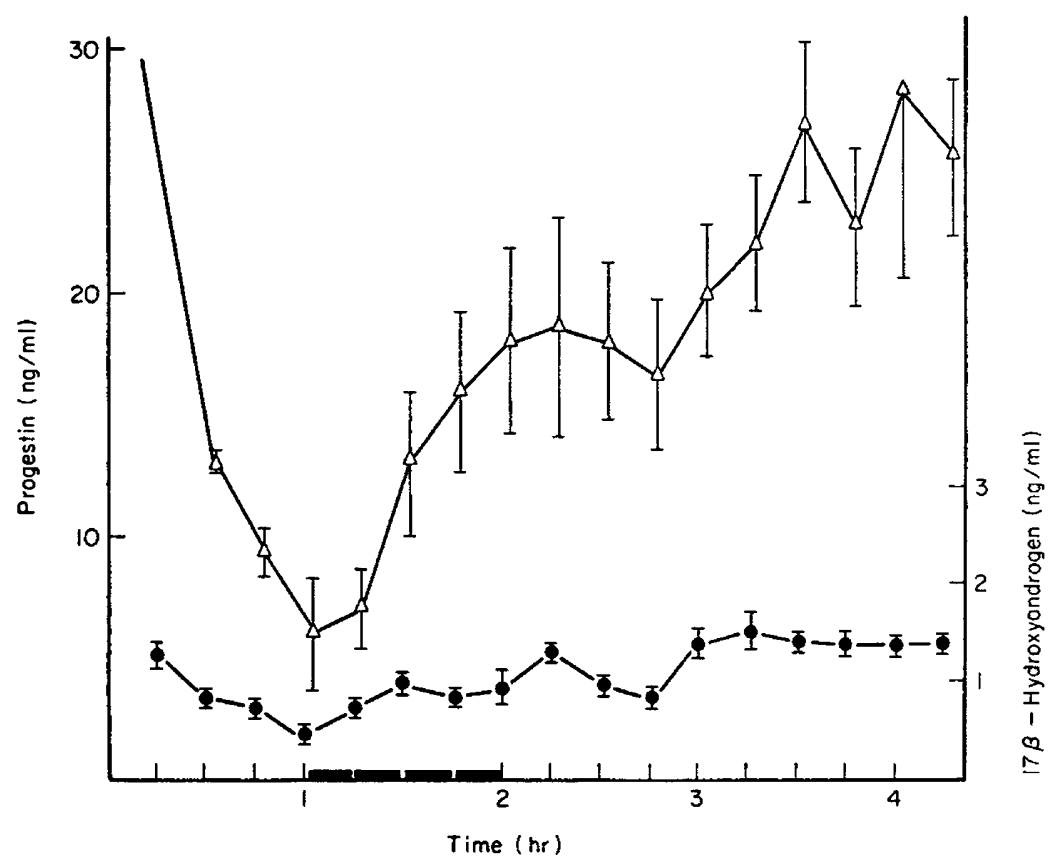

Texr-FIG. 5. Effect of $\mathbf{L H}$ on steroid secretion by rabbit interstitial tissue. The results are expressed as the mean and standard error of two experiments. $0,17 \beta$-Hydroxyandrogen; $\Delta$, progestin. The bar represents the period of exposure to LH.

end of the incubations had the equivalent of 16 and $40 \mathrm{ng} / \mathrm{ml}$ progestin. Oestrogens were not detected and androgens were close to the limit of sensitivity of our testosterone assay. Although there seemed to be some androgen secretion, the differences were not as dramatic as for the follicular incubations.

\section{DISCUSSION}

The follicles are generally regarded as the primary source of preovulatory oestrogen (Hisaw, 1947). Follicles may also contribute to preovulatory progestin secretion in the rat (Stoklosowa \& Nalbandov, 1971), hamster (Leavitt, Bosley \& Blaha, 1971) and rabbit (Hilliard \& Eaton, 1971; YoungLai, 1972b). The rabbit follicle is able to synthesize testosterone from acetate (Mills \& Savard, 1972) and has been implicated in testosterone secretion in vivo (Hilliard et al., 1973; YoungLai, 1973a). The present investigation with isolated follicles 
confirms and extends the observation that the rabbit follicles are better sources of androgens than of oestrogens and progestins when stimulated by $\mathrm{LH}$ alone.

Because of the well-known negative feedback rôle of androgen on the secretion of gonadotrophins, it is possible that follicular androgen serves to limit the amount of $\mathrm{LH}$ released by the pituitary. Recent evidence with androgen-insensitive mice suggests that androgens may be needed for normal ovarian function (Ohno, Christian \& Attardi, 1973), but gross ovarian function in rats is not affected by androgens (Neumann, von Berswordt-Wallrabe, Elger, Steinbeck, Hahn \& Kramer, 1970). Although it is known that steroidogenesis is related to meiotic maturation (Snyder \& Schuetz, 1973), evidence obtained in rats indicates that oocyte maturation is not mediated by progesterone (Lindner, Tsafriri \& Zor, 1974). The physiological rôle of androgens in the female rabbit warrants further investigation.

It is of interest that oestrogen is slowly released in a continuous manner for the duration of the experiment in vitro whereas progestin and $17 \beta$-hydroxyandrogen release ceases after $2 \mathrm{hr}$. This suggests that the follicles produce oestrogen continually whereas progestin and $17 \beta$-hydroxyandrogen production require constant stimulation. The last two groups of steroids probably represent material originally stored in the follicles which is released spontaneously. The continuous release of oestrogen and the fact that the follicles will respond to $\mathrm{LH}$ with an increased release of $17 \beta$-hydroxyandrogen after $15 \mathrm{hr}$ in the cold (Text-fig. 4) suggest that the cells remained viable.

The precursors of $17 \beta$-hydroxyandrogen affected by stimulation with $\mathrm{LH}$ remain in doubt. If progesterone fulfilled this function one would have expected a fall in progestin values relative to the increase in 17 $\beta$-hydroxyandrogen as demonstrated by Moor, Hay, McIntosh \& Caldwell (1973) for progesterone and oestrogen in the sheep follicle. Gonadotrophins stimulate both synthesis and release of steroids (Eik-Nes, 1964). Differences in rate of release of progestin relative to androgen and the fact that the homogenates of follicles contained about sixfold more progestin before incubation could account for the observed effects. Moreover, it is known that LH has an inhibitory effect on the $17 \beta$ hydroxysteroid dehydrogenase for androstenedione (Boucek, Telegdy \& Savard, 1967; YoungLai, 1973b). Thus, it seems unlikely that the $\Delta^{4}$ pathway through progesterone would be activated for testosterone synthesis but it is possible that a steroid such as $\Delta^{5}$-androstene- $3 \beta, 17 \beta$-diol may be a logical precursor.

In view of the increasing evidence that steroids are released in a pulsatile fashion (West, Mahajan, Chavre, Nabors \& Tyler, 1973), it is noteworthy that testosterone and progestin secretion by the follicles showed a gradual increase and slow decline over a 3-hr period following a 15-min stimulation with LH (Text-fig. 3). This observation argues against the view that episodic release originates in the gonad unless one considers that a pulse could be of $3 \mathrm{hr}$ duration. With a similar preparation using pituitaries, Weisz \& Lloyd (1972) showed that $\mathrm{LH}$ is released in a pulsatile manner when stimulated with median eminence extract. These authors also suggested that gonadal steroids are released episodically.

It is known that follicular cells have specific receptors for LH (Rajaniemi \& Vanha-Perttula, 1972; Kammerman, Canfield, Kolena \& Channing, 1972), 
which have been utilized for the assay of LH (Shirley \& Stephenson, 1973). It is only after the $\mathrm{LH}$ is bound that a cascade of events take place leading, among other things, to steroidogenesis. This could explain why androgen is not released in a pulsatile manner in the follicular incubations since pulse release probably represents secretion of stored material and, in these experiments, androgen secretion was minimal before the addition of $\mathrm{LH}$. It is also possible that exposure to $\mathrm{LH}$ for $1 \mathrm{hr}$ (Text-fig. 2) is more than ample and the only requirement is sufficient LH to saturate the binding sites on the follicular cells, as in the 15min exposure which gave an identical response with respect to androgen secretion (Text-fig. 3).

The absence of stimulation of oestrogen secretion by $10 \mu \mathrm{g} \mathrm{LH}$ is difficult to explain. Mills et al. (1971) found that rabbit follicles were extremely sensitive to $\mathrm{LH}$ resulting in a large incorporation of $\left[1-{ }^{14} \mathrm{C}\right]$ acetate into oestrogens. At lower levels of LH (Text-fig. 3), there was some stimulation of oestrogen secretion. Hilliard \& Eaton (1971) demonstrated that oestrogen secretion in vivo is increased by mating, and previous data indicate that follicular fluid oestrogen is enhanced by mating (YoungLai, 1972b). On the other hand, LH can terminate oestrogen secretion and promote progestin secretion in the oestrous rat (Hori, Ide \& Miyake, 1969). Thus, the high levels of LH used could be inhibitory for the aromatizing system.

Progestin secretion by interstitial tissue and its stimulation by $\mathbf{L H}$ is not novel (Major \& Kilpatrick, 1972). The low level of androgen secretion is contrary to a similar rôle for interstitial tissue in the human ovary (Savard $e t$ al., 1965), and also to the situation in vivo where the interstitial tissue of the rabbit is presumed to be involved in androgen secretion (Hilliard et al., 1973).

\section{ACKNOWLEDGMENTS}

Thanks are due to Dr G. E. Abraham, Dr B. V. Caldwell and Dr R. G. Wieland for steroid antisera and the Endocrine Study Section, National Pituitary Agency, National Institutes of Health, for gifts of ovine LH. This work was supported by the Medical Research Council of Canada, MA 4192, and the author is an M.R.G. Scholar.

\section{REFERENGES}

Abraham, G. E., Marshall, J. R. \& Danne, T. A. (1972) Disorders of ovulation. In Pathophysiology of Gestation, Vol. 1, p. 1. Ed. N. S. Assali. Academic Press, New York.

Abraham, G. E., Swerdlofy, R. S., Tulchinsky, D. \& Odeli, W. D. (1971) Radioimmunoassay of plasma progesterone. F. clin. Endocr. Metab. 32, 619.

Boucek, R. J., Telegdy, G. \& Savard, K. (1967) Influence of gonadotrophin on histochemical properties of the rabbit ovary. Acta endocr., Copenh. 54, 295.

Coulson, P., LiU, T. G., Morris, R. \& Gorski, J. (1972) Interaction of LH with the ovary. In Gonadotropins, p. 227. Eds. B. B. Saxena, C. G. Beling and H. M. Gandy. Wiley-Interscience, New York.

Eik-Nes, K. B. (1964) Effects of gonadotrophins on secretion of steroids by the testis and ovary. Physiol. Rev. 44, 609.

Gospodarowicz, D. (1964) The in vitro production of androgens by follicular tissue of rabbits. Acta endocr., Copenh. 47, 306.

HILL, R. T. (1937) Ovaries secrete male hormone. I. Restoration of the castrate type of seminal vesicle and prostate glands to normal by grafts of ovaries in mice. Endocrinology, 21, 495.

Hilliard, J. \& Eaton, L. W. (1971) Estradiol-17 $\beta$, progesterone and 20 $\alpha$-hydroxypregn-4-en-3-one in rabbit ovarian venous plasma. II. From mating through implantation. Endocrinology, 89, 522. 
Hilliard, J., Scaramuzzi, R. J. \& Pang, S. (1973) Release of testosterone from rabbit ovaries in vivo. Fedn Proc. Fedn Am. Socs exp. Biol. 32, 12.

Hilliard, J., Spies, H. G. \& SaWyer, G. H. (1969) Hormonal factors regulating ovarian cholesterol mobilization and progestin secretion in intact and hypophysectomized rabbits. In The Gonads, p. 55. Ed. K. W. McKerns. Appleton-Gentury-Grofts, New York.

Hisaw, F. L. (1947) Development of the Graafian follicle and ovulation. Physiol. Rev. 27, 95.

HoRI, T., IDE, M. \& MiKAYe, T. (1969) Pituitary regulation of pre-ovulatory estrogen secretion in the rat. Endocr. jap. 16, 351.

Kammerman, S., Ganfield, R. E., Kolrna, J. \& Channing, G. P. (1972) The binding of iodinated HCG to porcine granulosa cells. Endocrinology, 91, 65.

LEAvitT, W. W., Bosley, G. G. \& BlahA, G. G. (1971) Source of preovulatory progesterone. Nature, New Biol. 234, 283.

Lindner, H. R., Tsafriri, A. \& ZoR, U. (1974) The action of LH on cultured mammalian follicles: mechanism of induction of maturation division of the oocyte. Recent Prog. Horm. Res. 30, (in press).

Major, P. W. \& KILPATrick, R. (1972) Cyclic AMP and hormone action. F. Endocr. 52, 593.

Mills, T. M., Davies, P. J. A. \& SAvard, K. (1971) Stimulation of estrogen synthesis in rabbit follicles by luteinizing hormone. Endocrinology, 88, 857.

Mirls, T. M. \& SAvard, K. (1972) In vitro steroid synthesis by follicles isolated from the rabbit ovary. Steroids, 20, 247.

Mills, T. M. \& SAVARD, K. (1973) Steroidogenesis in ovarian follicles isolated from rabbits before and after mating. Endocrinology, 92, 788.

Moor, R. M., Hay, M. F., McIntosh, J. E. A. \& Caldwell, B. V. (1973) Effect of gonadotrophins on the production of steroids by sheep ovarian follicles cultured in vitro. F. Endocr. 58, 599.

Neumann, F., von Berswordt-Wallrabe, R., Elger, W., Steinbeck, H., Hahn, J. D. \& Kramer, M. (1970) Aspects of androgen-dependent events as studied by anti-androgens. Recent Prog. Horm. Res. 26, 337.

Ohno, S., Christian, L. \& Attardi, B. (1973) Role of testosterone in normal female function. Nature, New Biol. 243, 119.

Rajaniemi, H. \& Vanha-Pertulu, T. (1972) Specific receptor for LH in the ovary: evidence by autoradiography and tissue fractionation. Endocrinology, 90, 1.

Savard, K., Marsh, J. M. \& Rice, B. F. (1965) Gonadotrophins and ovarian steroidogenesis. Recent Prog. Horm. Res. 21, 285.

Shirlex, A. \& Stephenson, J. (1973) Progestin production in vitro by rabbit granulosa cells as an assay for luteinizing hormone. 7. Endocr. 58, 345.

Snedecor, G. W. \& Cochran, W. G. (1967) Statistical Methods, 6th edn. Iowa State University Press.

SNYDER, B. W. \& SChUETZ, A. W. (1973) In vitro evidence of steroidogenesis in the amphibian (Rana pipiens) ovarian follicle and its relationship to meiotic maturation and ovulation. F. exp. Zool. $183,333$.

Stoklosowa, S. \& Nalbandov, A. V. (1971) Luteinization and steroidogenic activity of rat ovarian follicles cultured in vitro. Endocrinology, 91, 25.

WeIsz, J. \& Lloyd, G. W. (1972) Some aspects of CNS-pituitary-ovarian interrelationship. In Gonadotropins, p. 673. Eds. B. B. Saxena, G. G. Beling and H. M. Gandy. Wiley-Interscience, New York.

West, G. D., Mahajan, D. K., Ghavre, V. J., Nabors, G. J. \& Tyler, F. H. (1973) Simultaneous measurement of multiple plasma steroids by radioimmunoassay demonstrating episodic secretion. 7. clin. Endocr. Metab. 36, 1230.

YoungLaI, E. V. (1972a) Steroid secretion and the aromatization of androgens by rabbit thecal cells. Endocrinology, 91, 1267.

YoungLar, E. V. (1972b) Effect of mating on follicular fluid steroids in the rabbit. F. Reprod. Fert. 30, 157.

YoungLaI, E. V. (1973a) Biotransformation of pregnenolone and progesterone by rabbit ovarian follicles and corpora lutea. Acta endocr., Copenh. 74, 775.

YoungLAI, E. V. (1973b) The bioconversion of androstenedione and testosterone by rabbit granulosa cells and the effect of ovine LH on thecal aromatization. Steroids Lipids Res. 4, 11. 